\section{Monta näkökulmaa ajattelun kehityksen malleihin}

Kallio Eeva (toim.) (2016). Ajattelun kehitys aikuisuudessa.

Kohti moninäkökulmaisuutta. Suomen Kasvatustieteellinen Seura. Kasvatusalan tutkimuksia 71. Jyväskylän yliopistopaino, Jyväskylä. 382 sivua. ISBN 978-952-5401-73-8

RUNSAS ARTIKKELIKOKOELMA sisältää 14 artikkelia 17 kirjoittajalta, mukaan lukien julkaisun toimittajan kokoava ja laajasti orientoiva johdatusartikkeli. Kirjoittajat ovat koulutuksen ja opetuksen asiantuntijoita: dosentteja, tohtorikoulutettavia ja professoreita.

Ensimmäinen osa johdattaa asiaan, toisessa osassa vastataan teoksen nimeen, ja kolmas osa täydentää kuvaa tarkastelemalla näkemyksiä aikuisen oppimisen ja toimintakyvyn kehittymisen yhteyksistä. Perinteisen kehityspsykologisen ja sosiaalipsykologisen tieteen orientaatioiden ja käsitteellistämisen lisäksi teos nostaa esille moraalifilosofista pohdintaa, jolla myös teoksen anti ja teeman käsittelyn uutuus vahvasti lepää.

\section{ALUKSI RAJATAAN KENTTÄ}

Johdantoartikkelissaan Eeva Kalkimusalueen, jossa painottuu eurooppalainen ja angloamerikkalainen perinne. Useassa artikkelissa lähdetään liikkeelle teeman ehdottomasta, psykologisen tutkimuksen puolelta tulevasta auktoriteetista Jean Piaget'sta. Näin Kalliokin tekee, mutta ehdottomasti julkaisun tarkoituksena on jatkaa siitä, mihin Piaget jäi. Kallio hahmottelee tutkimuksen kehitystä kohti moninäkökulmaisuutta, johon muut kirjoittajat artikkeleissaan tarttuvat.

Johdatusosan toinen artikkeli tuo mukaan filosofisen näkökulman, joka on vahvasti läsnä koko julkaisussa. Miira Tuominen kälio rajaa teoksen käsittelemän tut-

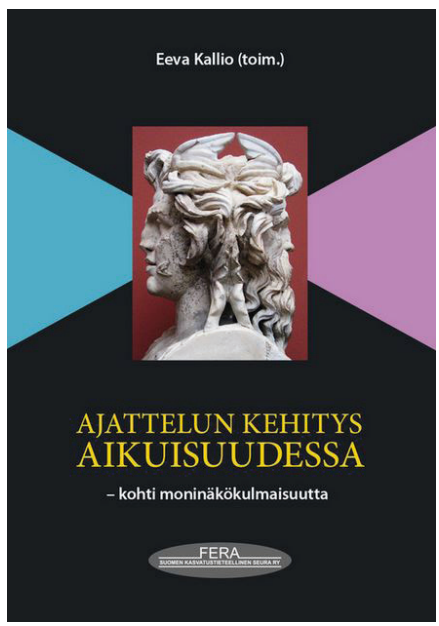

sittelee antiikin filosofikoulujen näkemyksiä artikkelissaan, jossa mielenkiintoa motivoi kysymys, ”... millä perusteilla ja millä tavoilla ihmisen ajattelun voidaan katsoa kehittyvän paremmaksi ja jopa muuttavan ihmistä paremmaksi" (s. 58). Ajattelun kehityksestä syntyy jännite, joka elää lukijan mielessä koko lukukokemuksen ajan.

MITEN TIETEELLINEN AJATTELU KEHITTYY

Ensimmäisen jakson otsikko on "Kehitysvaihemallit: tieto, käsi- 
tykset, moraali”. Hannele Seppälä tarkastelee tieteellisen ajattelun kehittymistä loogisen ajattelun taitojen kehittymisenä ja eri tieteiden paradigmoihin sisältyvien tietokäsityksinä. Lukijalle käy yhä selvemmäksi, että teos ei tavoittele yhtä vastausta ajattelun kehitykseen aikuisuudessa vaan tarjoilee erilaisia näkökulmia ja malleja.

Sari Lindblom-Ylänne ja Minna Koutaniemi menevät vielä pidemmälle ja esittelevät erilaisia tieteellisen ajattelun ja tietokäsitysten tutkimusmenetelmiä. Tieteellisen ajattelun tutkimuksen kontekstina toimivat opiskelijoiden yliopistoopinnot, joiden aikaista ajattelun kehitystä artikkelissa problematisoidaan.

Anna-Maija Pirttilä-Backman ja Salla Ahola tarkastelevat puolestaan henkilökohtaisten tietokäsitysten ja yhteisten arkiteorioiden syntymistä. Jokainen yhteisö rakentaa ne itselleen sopivaksi malliksi siitä, mihin tietäminen perustetaan.

Soile Juujärvi liittää filosofian ja ajattelun kehityksen yhteen moraalifilosofian kautta. Hän käsittelee Piaget'n teorian jatkajien Lawrence Kohlbergin ja Carol Gilliganin teorioita oikeudenmukaisuuden ja huolenpidon rakentumisesta oleelliseksi osaksi aikuisen kehitystä. Yhä vahvemmin aikuisen ajattelun kehitys kiinnitetään tietoon ja siihen, että kun kokemuksellinen tieto lisääntyy, aikuisen ajatteluun kehittyy moninäkökulmaisuutta, jossa tietoisuus rakentuu myös sosiaaliselle vastuullisuudelle ja toimii moraalisen ajattelun optiona. Am- matillisen osaamisen ja etiikan kehitysvaiheita on tunnetusti perusteltu tähän moraalifilosofiaan.

Moraalin määritelmää laajentaa Jaana-Piia Mäkiniemen artikkelissaan, jossa sosiaalipsykologinen teorianmuodostus korostaa moraaliajattelun yhteisöllisyyttä. Samalla tuodaan selkeästi esille Klaus Helkaman merkittävä panos käsityksen tutkimukselle.

\section{OPPIMISEN MONET KONTEKSTIT}

Toisessa osassa "Oppiminen, tieto ja toimintakyky" avataan ikkunoita oppimiseen ja kehittymiseen erilaisten kontekstien kautta. Mirjamaija Mikkilä-Erdman kuljettaa konteksteja sekä eri tutkimusparadigmoista että yliopistokoulutuksista, joissa oppimisratkaisut ovat keskeisiä käsitteellisen ajattelun kehityksessä. Varmoja vastauksia esimerkiksi eri menetelmien, teknologian tai oppimisympäristöjen eroista ei ole, ja artikkeli nostaakin esiin ratkaisua odottavia kysymyksiä myös opettajankoulutuksiin.

Päivi Tynjälä on itselleen tutun teeman, asiantuntijan tiedon ja ajattelun kehityksen, parissa artikkelissaan, jossa päädytään integroivaan ajatteluun asiantuntijatiedon korkeimpana asteena. Näkemys yhdistyy hyvin integratiivisen pedagogiikan malliin, jota Tynjälä on viime vuosina kehitellyt. Asiantuntijan ajattelun kehittymistä pohtii myös Auli Toom hiljaista tietoa käsittelevässä artikkelissaan.

Artikkelissaan "Aikuisiän myönteisen persoonallisuuden kehityksen yhteydet psykologiseen ja so- siaaliseen toimintakykyyn" Katja Kokko ja Helen Shehadeh avaavat näkökulmia persoonallisuuspsykologian kontekstista ajattelun kehitykseen ja sen yhteyksiin ihmisen persoonallisuuteen. He hyödyntävät jokseenkin ainutlaatuiseksi luonnehdittavaa, Lea Pulkkisen vuonna 1968 aloittaman "Lapsesta aikuiseksi" -tutkimuksen pitkittäisaineistoa. Siinä seurattiin silloisten kansakoulun toisluokkalaisten lasten kehitystä aikuisiksi ( $\mathrm{N}=173$ tyttöä ja 196 poikaa). Heidän esittämänsä tulos antaa paljon ajattelemisen aihetta aikuisten ajattelun kehityksen tutkimiselle ja etenkin aikuiskasvatukselle.

Dekkarigenreä hyväksi käyttäen ja jännitteen säilymiseksi en kerro kaikkia tuloksia, mutta empiirisen datan perusteella näyttää, että "persoonallisuuden kasvu on epätyypillinen aikuisuuden kehityskulku" (s. 289-290). Etenkin viisaudessa saattaa olla pakko taipua platonilaiseen käsitykseen sen kehittymisen kronologisesta vaiheesta.

\section{MONINÄKÖKULMAISEEN \\ AJATTELUUN}

Kolmannessa osassa, epilogissa, haetaan esimerkiksi kotipesää moninäkökulmaiselle ajattelulle. Laura Mononen, Päivi Tynjälä ja Eeva Kallio tarkastelevat systeemiteorioita ja niiden näkökulmia kokonaisvaltaiselle ajattelulle ja oppimiselle.

Sama pyrkimys on J. P. Jakosella ja Matti Kamppisella jotka kirjoittavat Ken Wilberin integraaliteoriasta. Se putoaa teokseen 
ikään kuin toiselta galaksilta, tai ainakin ei-niin-eurooppalais-anglo-amerikkalaisesta kontekstista henkisyyden ja evoluution yhdistävällä näkemyksellään. Ajattelun tutkimuksen vakuuttavuuden takeena kirjoittajat päättävät artikkelinsa reiluun kritiikkiin, joka paljastaa integraaliteorian heikkouksia ja samalla kirjoittajien vahvuuksia.

Päätösartikkelissa Miira Tuominen palaa filosofian näkökulmasta tarkastelemaan ajattelua koskevaa kehityspsykologista käsitteistöä kriittisesti itse tietoon, tiedon ristiriitaisuuteen, totuuteen ja moraalifilosofiaan liittyvien eettisten näkemysten monimuotoisuuden osalta. Erityisesti hän kritisoi perinteisiä, kehitystä kuvaavia vaihemalleja.

\section{LUKUKOKEMUS OHJAA REFLEKTIOON}

Teoksen parasta antia on se, että se ohjaa lukijan väistämättä reflektioon, jonka ainekset löytyvät toisaalta kehityspsykologisten vaihemallien tai vaikkapa empiirisen pitkittäistutkimuksen tärkeiden tulosten törmäyttämisestä filosofisiin käsitteisiin tiedosta, logiikasta ja totuudesta. Eeva Kallion teksteistä on luettavissa tämä mahdollinen törmäytys ja jopa tietoinen tarkoitus olla antamatta yksiselitteisiä vastauksia.

Teoksen mahtipontinen nimi, Ajattelun kehitys aikuisuudessa, saattaa harhauttaa lukijaa - viestihän se, että nyt saadaan lukea, kuinka ajattelu kehittyy. Sen sijaan lukijalle tarjoutuu mahdollisuus lukea ajattelun kehityksen ajatusmalleista, mallien taustalla olevista tutkimuksista ja näkökulmista.

Alaotsikon lupaama moninäkökulmaisuus osoittautuu oletettua rajatummaksi. Kehitysmallien ja oppimisen tutkimuksen näkökulmat rajautuvat lähinnä kognitiiviseen kehityspsykologiaan ja sen jatkumona toimivan konstruktiivisen psykologian ja tietoteorian diskursseille.

Vaikka monessa artikkelissa viitataan erilaisiin konteksteihin ja historiallisuuteen, varsinainen kulttuurihistoriallinen kokonaisnäkökulma puuttuu. Integraaliteoriassa se taas ylitetään liian suurella hyppäyksellä. Voisi odottaa, että esimerkiksi työn, työvälineiden, elinympäristöjen, kaupungistumisen kehitysvaiheet olisivat yhtä kiinnostavia aikuisen ajattelun kehityksen kehikkoja kuin julkaisuun valittu "varsinaisen ajattelun" kehityksen tutkimus.

Samalla tavalla teoksesta rajautuvat ulos psykologisista näkökulmista psykodynaamiset ja neuropsykologiset näkemykset, valtaa ja hallintaa koskevat yhteiskuntakriittiset diskurssit. Näin kehollisuuden ja ruumiillisuuden näkökulma jää sivuun, vaikka sen luulisi olevan aktuelli tutkimusnäkökulma tähänkin teemaan samoin kuin tekoälyn ja kommunikaatioteknologian, "ajattelun proteesien", muutosten vaikutukset ajattelun tuottamiseen ja tapoihin. Entä mitä tapahtuu ajattelulle vanhuudessa - kehon radikaaleissa muutoksissa tai kommunikoitaessa palvelurobotin kanssa?

\section{KÄSITTEET KAIPAAVAT TARKENTAMISTA}

Monessa artikkelissa käytetään rennosti 'tiedon' käsitettä, vaikka usein ilmiselvän informaation, datan tai jopa kohinan nimittäminen tiedoksi on kyseenalaista. Myös tieto, tietoisuus ja tieteellisyys saavat niin lähekkäisen aseman toisiinsa, että tieteelliseen logiikkaan perustuva ajattelu nousee implisiittisesti enemmän kehittyneeksi ja kehittäväksi kuin jokin muu tie.

Miira Tuomisen filosofisen kritiikin toteamus, "ei vallitse täyttä käsitteellistä selvyyttä siitä, mitä aikuisuuden kehittyneellä ajattelulla tarkoitetaan" (s. 375), ei tarkoita teoksen pyrkimyksen epäonnistumista, vaikka usein tutkimusten toivotaan vastaavan edes käsitteen selkiytymiseksi. Teoksen toimittajakin tietää tämän ja johdannossaan varoittelee käsitteellisestä sumeudesta, mikä on toki yleisesti kasvatustieteellisten paradigmojen yksi dialogisuusongelma.

Toimittaja on tehnyt työtä sen eteen, että artikkeleissa pyritään luomaan kokonaisuutta ja keskinäisiä yhteyksiä. Nimi- ja asiahakemistot olisivat tarpeellisia näinkin käsikirjamaisessa teoksessa.

Teos on tuore ja vahva näkökulma aikuisen ajattelun kehityksen ja ajattelun filosofian teemoihin opiskelua ja jatkotutkimuksia varten. Filosofiassaan ja tiedoillaan se pamauttaa lukijan itsereflektiot liikkeelle, tuottaa ajattelemisen harjoitusta ja ajattelun kehittymiselle tarpeellisia lisäkokemuksia.

HEIKKI PASANEN, FT 